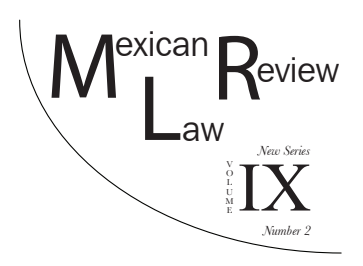

\title{
MEXICAN STRUCTURAL REFORMS AND THE UNITED STATES CONGRESS*
}

\author{
Ana María Zorrilla NoriegA**
}

\begin{abstract}
Diverse structural reforms were enacted in Mexico during 2013 and 2014. Since these reforms were made on the constitutional level, they must be translated into specific laws and regulations; and more importantly, they must be implemented in an efficient manner. As Mexico is experiencing this transformation, its relations with United States are also evolving. This transition will probably imply new challenges with regard to different aspects of the bilateral relationship. Considering that the U.S. Congress plays a significant role in shaping those relations, the purpose of this article is to analyze some significant issues that have received or are likely to receive special attention in the U.S. Congress. This article is divided into seven sections. The first one presents an analysis of the complexity of U.S.-Mexico relations. The second part includes an explanation regarding Mexican reforms of 2013 and 2014, as well as the resulted transition in the bilateral relationship. The next four sections address significant pillars of this relationship: security, economy, migration, and energy. Each of these parts comprises a general overview of the U.S.-Mexico relations in that specific matter; a description of the viewes of the Mexican government and reforms of its constitutional and legal framework; and an analysis of the most relevant legislative actions that have recently taken place or are likely to receive attention in the U.S. Congress. The seventh section addresses other relevant aspects that should be taken into account in the policyand law-making processes.
\end{abstract}

KeY wORDs: Constitutional reforms; U.S. Congress; U.S.-Mexico relations; legislative processes.

* This article is the result of a research project conducted as a Fulbright-García Robles grantee in the LL.M. Program on Law and Government at American University Washington College of Law, Washington, D.C.

** Coordinator of the Law and Public Policy Clinic at the Law Academic Department of the Instituto Tecnológico Autónomo de México (ITAM), Mexico City. Email: ana.zorrilla@itam.mx.

\section{1}


Esta revista forma parte del acervo de la Biblioteca Jurídica Virtual del Instituto de Investigaciones Jurídicas de la UNAM

Resumen. Diversas reformas estructurales fueron promulgadas en México durante 2013 y 2014. Dado que se realizaron a nivel constitucional, estas reformas deben traducirse en leyes secundarias y reglamentos y, aún más importante, deben implementarse de una manera eficiente. Mientras México está experimentando esta transformación, su relación con Estados Unidos de América (EE. UU.) también está evolucionando. Esta transición probablemente implicará nuevos retos en los diferentes aspectos de la relación bilateral. Considerando que el Congreso de EE.UU. desempeña un papel significativo en la configuración de dicha relación, el propósito de este artículo es analizar algunos asuntos que han recibido o probablemente recibirán atención en el Congreso de los Estados Unidos. El artículo se divide en siete secciones. En la primera se presenta un análisis de la complejidad en las relaciones entre México y EE.UU. En la segunda se incluye una explicación de las reformas promulgadas en México durante 2013 y 2014, así como un análisis de los efectos que dichas reformas han ocasionado en la relación bilateral. En los siguientes cuatro apartados se estudian pilares fundamentales de la relación: seguridad, economía, migración y energía. Cada una de estas secciones comprende una descripción de ese aspecto concreto; un análisis de la perspectiva mexicana y de las reformas a su marco jurídico; y un estudio de acciones legislativas relevantes que se han realizado, o que probablemente reciban atención, en el Congreso de EE.UU. En la séptima sección se abordan aspectos relevantes que deben considerarse en los procesos tanto legislativos como de política pública.

Palabras clave: Reformas constitucionales; Congreso de EE.UU.; relaciones EE.UU.-México; procesos legislativos.

\section{TABLE OF CONTENTS}

I. INTRODUCTION

II. The Gomplex Scope of U.S.-Mexico Relations ............................. 74

III. Mexican Structural Reforms: A Time of Transition for the BilaTERAL RELATIONSHIP.

IV. SECurity Gooperation ........................................................... 76

1. General Overview................................................................. 76

2. Mexican Government's Perspective ......................................... 77

3. Issues In the U.S. Congress .................................................... 79

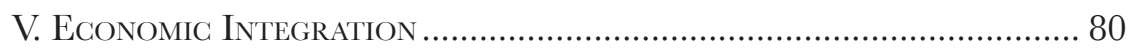

1. General Overview .................................................................... 80

2. Mexican Government's Perspective ......................................... 81

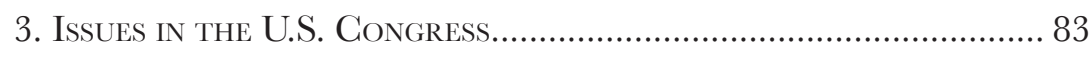

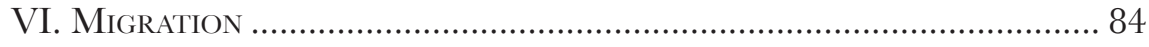

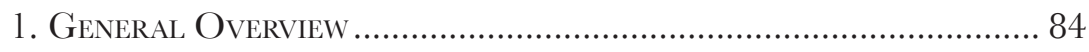

2. Mexican Government's Perspective .......................................... 85 


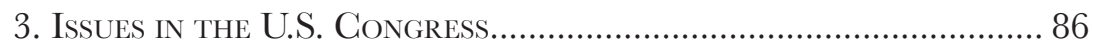

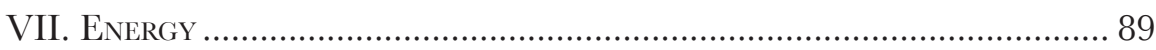

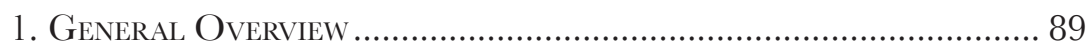

2. Mexican Government's Perspective ......................................... 89

3. Issues in the U.S. Congress.................................................... 91

VIII. Other ReLevant Issues ............................................................ 92

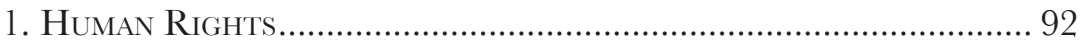

2. Border IsSUES ........................................................................ 93

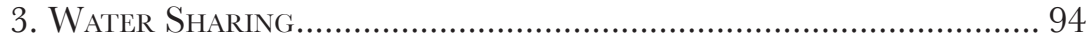

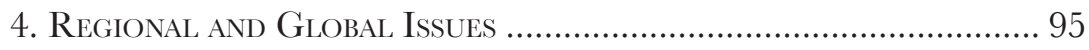

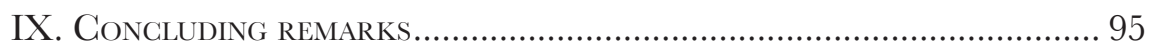

\section{INTRODUCTION}

The United States (U.S.) and Mexico have shaped "one of the strongest and most productive relationships in the world. No two countries anywhere engage so intensely on a daily basis, cooperate across such a wide and varied spectrum of issues, and affect the economy and society of the other so profoundly."

The complexity of the relationship between these two countries lies not only in the inherent characteristics of both societies but also in the policy and political objectives that both governments have. For instance, while immigration and border issues have been an important part of the agenda for a long time, economic matters were the most relevant aspect of the bilateral relationship during the nineties and security became the prominent topic during the last years. Today, the two countries are betting on the future by focusing on a relatively new issue that captures the essence of their long-term objectives: energy. Undoubtedly, the way these issues are addressed is a process of constant change that is marked by internal political debates and decisionmaking processes.

Taking into consideration that U.S.-Mexico relations are experiencing a time of transition due to diverse structural reforms that were approved in Mexico during 2013 and 2014, and that the U.S. Congress plays a significant role in shaping those relations, the purpose of this paper is to study the current status of the bilateral relationship. Particularly, its main objective is to address some significant issues that have received or are likely to receive special attention in the U.S. Congress.

This article is divided into seven sections. The first one presents an analysis of the complexity of U.S.-Mexico relations. The second part includes an ex-

1 Commission on Mexico-U.S. Relations, Inter-American Dialogue, A More Ambitious Agenda 1 (2013). 
planation regarding Mexican structural reforms of 2013 and 2014, as well as the resulted transition in the relationship with the U.S. The next four sections address significant pillars of the bilateral relationship: security cooperation, economic integration, migration, and energy. Each of these parts comprises a general overview of the U.S.-Mexico relations in that specific matter; a description of the views of the Mexican government and reforms of its constitutional and legal framework; and an analysis of the most relevant legislative actions that have taken place or are likely to receive attention in the U.S. Congress. The seventh section addresses other relevant aspects that should be taken into account in the policy- and law-making processes. Finally, some concluding remarks are included.

\section{The Complex Scope of U.S.-Mexico Relations}

Sharing a 2,000-mile border, with over 1.25 billion dollars of two-way trade, and approximately one million legal border crossings each day, the scope of bilateral relations between the U.S. and Mexico is broad and complex. ${ }^{2}$ It comprises far-reaching social, commercial, and cultural bonds. As the famous Mexican writer Octavio Paz once stated, the border between Mexico and the U.S. "is political and historical, not geographical."3

About 33 million U.S. residents are of Mexican origin and a million American citizens live in Mexico. ${ }^{4}$ Consequently, the relations between the two countries have a direct impact on the lives of millions of persons. Being aware of this reality, both nations have made a commitment to "enhance this cooperation to fully leverage their inevitable and accelerating economic and demographic integration." ${ }^{5}$

Luis Rubio points out that the neighborhood calls for new ideas and new ways of looking at problems. ${ }^{6}$ Moreover, the success of Mexico in resolving its difficulties has a major impact upon the U.S. ${ }^{7}$ For instance, if Mexico resolves the current wave of violence and insecurity that has affected investment and impacted economic performance, it could become a formidable partner for economic growth. ${ }^{8}$ Similarly, if Mexico successfully promotes a more competitive economy in the energy sector, both migration and investment flows could change dramatically.

2 U.S. Department of State, Bureau of Western Hemisphere Affairs, U.S. Relations with Mexico (2013), available at http://www.state.gov/r/pa/ei/bgn/35749.htm

3 Octavio Paz, Mexico and the U.S.: Ideology and Reality, in Mexico Matters: Change in Mexico and its Impact Upon the United States 6 (Luis Rubio, Wilson Center, 2013).

4 Inter-American Dialogue, supra note 1, at 1; see also and U.S. Department of State, supra note 2 .

5 Id.

6 Rubio, supra note 3 , at 5.

7 Id.

$8 \quad I d$. 
Esta revista forma parte del acervo de la Biblioteca Jurídica Virtual del Instituto de Investigaciones Jurídicas de la UNAM

\section{Mexican Structural Reforms: A Time of Transition FOR THE BILATERAL RELATIONSHIP}

Presidential elections in the U.S. and Mexico coincide once every 12 years. While Enrique Peña Nieto was inaugurated President of Mexico on December 1, 2012, Barack Obama began his second term on January 21, 2013. This concurrence poses an opportunity for both governments to explore what needs to be done in order to achieve a more cooperative and productive relationship. ${ }^{9}$

After his inauguration, President Peña Nieto announced that his government would work on five strategic pillars: reducing violence, combating poverty, enhancing education, boosting economic growth, and fostering global responsibility. ${ }^{10}$

At the earliest stage of the administration, President Peña Nieto promoted the signature of the "Pact for Mexico," a political agreement signed by the leaders of the three major political parties: Institutional Revolutionary Party (PRI, the President's party), National Action Party (PAN), and Party of the Democratic Revolution (PRD). ${ }^{11}$ This agreement contained commitments on key issues for the nation and functioned as a first step to discuss diverse legislative proposals. ${ }^{12}$

Those multi-party negotiations were certainly essential for the enactment of a variety of structural reforms: political, antitrust, financial, fiscal, on education, on telecommunications, on energy, on transparency, among others. These reforms were made on the constitutional level and thus must be translated into specific laws and regulations that will have a direct impact on the economic and social conditions of the country.

Even at the constitutional level, these reforms contain significant changes for Mexico. For instance, the political reform establishes reelection for federal and local congressmen, senators, and mayors; requires at least 50 percent of congressional candidacies to be reserved for women; and shortens presidential transitions: the President, elected in July, will now take office on October 1, rather than December $1 .{ }^{13}$ Another illustrative example is the fiscal reform, which is aimed to tax junk food and sugary drinks; increase taxes on upper income brackets; and formalize 5.2 million small businesses through an electronic tax system. ${ }^{14}$

\footnotetext{
9 Inter-American Dialogue, supra note 1 , at 2.

10 "5 Ejes para Lograr uNa Democracia de Resultados," (Apr. 27, 2014), http://www. presidencia.gob.mx/5-ejes-para-lograr-una-democracia-de-resultados /

11 In November 2013, the PRD withdrew -at least temporarily- from the Pact for Mexico.

12 See "PACTO POR MÉXICO," (Apr. 27, 2014), http://pactopormexico.org/acuerdos/

13 Andrés Sada, Explainer: Mexico's 2013 Reforms, Americas Society/Council of the Americas, (Apr. 27, 2014), http://www.as-coa.org/articles/explainer-mexicos-2013reforms\#telecoms

14 Id.
} 
Clare Ribando, from the Congressional Research Service (CRS), observes that as Mexico is experiencing this "major domestic shift" the relations between the U.S. and Mexico are also evolving. ${ }^{15}$ This transition may lead to advances in some aspects of the bilateral relationship, while setbacks may take place in others. ${ }^{16}$ For instance, analysts hope that security cooperation may continue even if bilateral attention focuses more on trade and energy than in the recent past. ${ }^{17}$ Throughout this process, maintaining strong bilateral cooperation while protecting the U.S. interests is likely to be a crucial purpose for the Congress. ${ }^{18}$

\section{Security Cooperation}

\section{General Overview}

The Mérida Initiative is an unprecedented partnership between the two countries aimed to "address violence and criminality while strengthening the rule of law and the respect for human rights." ${ }^{19}$ For this initiative, Congress appropriated nearly $\$ 2.5$ billion from 2008 to $2015 .^{20}$

When the Mérida Initiative was signed, in 2007, the U.S. assistance was focused on training and equipping Mexican forces. However, President Obama's administration replaced this heavy emphasis on military equipment with "a more comprehensive bilateral strategy that seeks to reduce the role and influence of organized crime." 21

Since 2010, the Mérida Initiative focuses on four pillars: disrupting organized criminal groups; enhancing the capacity of Mexican institutions to sustain the rule of law; improving the border management; and building strong and resilient communities. ${ }^{22}$

15 Clare Ribando Seelke, Cong. Research Serv., R42917, Mexico: Background and U.S. Relations 11 (Jan. 30, 2014).

16 Id. at 27.

17 Id.

18 Id. at 1.

19 U.S. Department of State, supra note 2.

20 Glare Ribando Seelke and Kristin Finklea, Cong. Research Serv., R41349, U.S.Mexican Security Cooperation: The Mérida Initiative and Beyond, summary (Jan. 15, 2016).

21 Shannon K. O'Neil, Senior Fellow for Latin America Studies, Council on Foreign Relations, testimony before the U.S. Senate Committee on Foreign Relations, Subcommittee on Western Hemisphere and Global Narcotics Affairs, Hearing on Security Cooperation in Mexico: Examining the Next Steps in the U.S.-Mexico Security Relationship, at 2 (Jun. 18, 2013).

22 U.S. Department of State, supra note 2; see also Ribando, Cong. Research Serv., supra note 15 , at 18 . 
As the U.S.-Mexico security cooperation strategy has evolved, there has been a dramatic increase in violence: while in 2007 there were over two thousand drug-related homicides annually, by 2012 the number escalated to more than twelve thousand. ${ }^{23}$ This rise in violence is not only a result of drug trafficking; criminal organizations have diversified into numerous illicit businesses (kidnapping, robbery, human trafficking, among others) and thus prey more directly on the local population. ${ }^{24}$

As it will be explained in the following section of this work, President Peña Nieto initially shifted the national security strategy from combating drug trafficking toward reducing violence. ${ }^{25}$ With regard to the new security strategy, on May 2, 2013 President Obama stated that "it is obviously up to the Mexican people to determine their security structures and how it engages with other nations, including the United States. ${ }^{\prime 26}$ He emphasized that his administration supports "the Mexican government's focus on reducing violence [and looks] forward to continuing [...] good cooperation in any way that the Mexican government deems appropriate." ${ }^{27}$

Several cases of human rights abuses allegedly involving security officials, such as the disappearance of 43 students in the state of Guerrero (September 2014), have demonstrated the profound problems of corruption and impunity in Mexico. For this reason, Mexican government has received severe criticism, which has generated pressure to hasten the nation's criminal justice system transition.

\section{Mexican Government's Perspective}

Ribando observes that while "bilateral efforts have yielded some positive results, the weakness of Mexico's criminal justice system has hindered the effectiveness of some anti-crime efforts." 28 In this regard, Mexican government has taken some measures to advance in the implementation of the 2008 constitutional reform, which main purpose is the transition from an inquisitorial justice system to an oral, adversarial, and accusatory one in which human rights for victims and the accused should be protected. Although the deadline for this implementation is 2016, "the urgency of a properly functioning court system is clearer than ever." 29

\footnotetext{
23 O’Neil, supra note 21, at 3.

24 Id.

25 Id.

26 The White House, Office of the Press Secretary, Remarks by President Obama and President Peña Nieto of Mexico in a Foint Press Conference" Press Release, (Apr. 27, 2014). , available at http:// www.whitehouse.gov/the-press-office/2013/05/02/remarks-president-obama-and-presidentpena-nieto-mexico-joint-press-conf

27 Id.

28 Ribando, Cong. Research Serv., supra note 15, at 18.

29 Duncan Wood, Director, Mexico Institute, Woodrow Wilson International Center for Scholars, testimony before the U.S. Senate Committee on Foreign Relations, Subcommittee
} 
President Peña Nieto outlined a security strategy under which human rights are protected by implementing a policy that involves all levels of government and requires civic participation. ${ }^{30}$ Although this security strategy does not abandon the fight against organized crime, its primary goal is to reduce violent crime. ${ }^{31}$ Along with this emphasis on reducing violent crime, President Peña Nieto has adjusted the process and priorities of U.S.-Mexican efforts. ${ }^{32}$

Duncan Wood identifies two central themes in Mexico's security strategy: coordination and violence reduction. ${ }^{33}$ In the first case, President Peña Nieto centralized the decision-making power into the Interior Ministry and brought the Office of Public Security under its purview. In addition to these structural changes, there has been coordination between all government ministries, and between the federal and state governments. In the second case, the Office of Prevention and Citizen Participation will "invest heavily in social programs and citizen engagement strategies at the local level in high risk communities." 34

As a result of the structural changes of the security strategy, the Interior Ministry is now the principal entity through which the Mérida Initiative intelligence is channeled. ${ }^{35}$ The Mexican government has requested increased assistance for judicial reform and prevention efforts, but has limited the U.S. involvement to certain operations related to law enforcement and intelligence. ${ }^{36}$ Additionally, the Mexican government has supported efforts to enact gun control and to combat gun trafficking from the U.S. to Mexico, and has identified money laundering as a field in which bilateral efforts could be strengthened. ${ }^{37}$

To conclude, the Mexican government is focused on reinforcing the institutions and the coordination among the various actors in charge of security while using the bilateral mechanisms with the U.S. to exchange intelligence and technology. However, there are still important pending issues to be discussed in Mexico that could affect the broad security policy in the country, such as unified police (mando único) at the state level, prison reform, and marihuana legalization, just to mention the most important ones.

on Western Hemisphere and Global Narcotics Affairs, Hearing on Security Cooperation in Mexico: Examining the Next Steps in the U.S.-Mexico Security Relationship (Jun. 18, 2013).

30 Ribando, Cong. Research Serv., supra note 15, at 7.

31 Id.

32 Id. at 18-19.

33 Wood, supra note 29.

34 Id.

35 Ribando, Cong. Research Serv., supra note 15, at 19.

36 Id.

37 Id. 


\section{Issues in the U.S. Congress}

Many hearings had been held in the Congress in order to determine how the Mexican security strategy aligns with the U.S. interests and thus reevaluate some types of Mérida Initiative funding. According to the CRS, when examining the future of the Mérida Initiative, Congress may seek to ensure that those who implement the Initiative have adequately developed metrics to measure progress. ${ }^{38}$ Considering the achieved level of progress, the Initiative may be deemed sufficient or insufficient; in the latter case, Congress might examine how it could be improved. ${ }^{39}$ Also, in order to evaluate if the U.S. funding is complementing or duplicating Mexican efforts, Congress may compare how much funding programs in Mexico are receiving from the Peña Nieto government. ${ }^{40}$

In this regard, Shannon K O'Neil proposes that the funds from the U.S. government in the Mérida Initiative should prioritize civilian (versus military) law enforcement institutions, focus on judicial reform, and move beyond the federal level. She suggests focusing resources on local efforts because this is where insecurity and violence are most concentrated and a shift to the state level would enable policymakers to address the varying nature of the violence. Finally, she proposes, the U.S. should prioritize the modernization of the U.S.-Mexico border. These initiatives (many already part of the Mérida framework) would help to reduce violence in Mexico by strengthening police forces, court systems, and local communities. ${ }^{41}$

The $114^{\text {th }}$ Congress has decided to continue funding the Mérida Initiative, as well as related domestic initiatives. In 2015, while the initial request for the Mérida Initiative was for $\$ 115$ million, Congress ultimately provided $\$ 143.6$ million. Additionally, some other funds were considered to support Mexican justice system's reform and its southern border program. ${ }^{42}$

The efforts under the Mérida Initiative framework to propel the judicial reform and prevent violence have taken on more urgency as Mexico has been struggling to prosecute those responsible for the serious cases involving allegations of human rights abuses that were previously described. ${ }^{43}$

In 2016, cooperation efforts are focused on securing Mexico's southern border, modernizing the U.S.-Mexico border, and developing a bilateral plan to combat heroin production and trafficking. ${ }^{44}$ Analysts comment that the

38 Glare Ribando Seelke \& Kristin M. Finklea, Cong. Research Serv., R41349, U.S.Mexican Segurity Cooperation: The Mérida Initiative and Beyond 31 (Jun. 12, 2013).

39 Id. at 32.

$40 \mathrm{Id}$

41 O'Neil, supra note 21, at 5-6.

42 Ribando and Finklea, Cong. Research Serv., supra note 20, at summary.

43 Glare Ribando Seelke, Cong. Research Serv., R42917, Mexico: Background and U.S. Relations 11 (Dec. 16, 2014).

44 Ribando and Finklea, Cong. Research Serv., supra note 20, at 26. 
U.S. Congress will probably monitor and evaluate how Mérida Initiative funding can best be used to help Mexico root out the corruption of its criminal justice system. ${ }^{45}$

In conclusion, while it is clear that the Mérida Initiative has significant challenges, it is also clear that it has become a unique bilateral instrument through which Mexican and U.S. institutions dialogue on issues of interest to both countries. This instrument has evolved with administration changes in both nations and it has been modified according to each country's objectives. Nonetheless, the dialogue caused by the Mérida Initiative creates communication channels that should be valorized and strengthened in order to face the serious security challenges of the region.

\section{ECONOMIC INTEGRATION}

\section{General Overview of U.S.-Mexico Relations}

Why is Mexican economic prosperity relevant for U.S. national interests? Mexico is the second largest export market and the third largest trading partner of the U.S. ${ }^{46}$ Moreover, during the past five years Mexican investment in the U.S. has grown by over 35 percent. ${ }^{47}$

On the other hand, the U.S. is by far Mexico's largest trading partner, as well as the largest source of foreign direct investment. ${ }^{48}$ Mexico is heavily dependent on the U.S. as an export market and as a source of tourism revenues, remittances, and investment. ${ }^{49}$ For all these reasons, economic indicators in Mexico tend to follow economic patterns in the U.S. ${ }^{50}$

The U.S., Mexico, and Canada are partners in the North American Free Trade Agreement (NAFTA), which entered into force in 1994. The NAFTA "achieved broader and deeper market openings than any prior trade agreement anywhere in the world" by eliminating tariffs on all industrial goods; opening a broad range of services; providing a high standard of protection for patents, trademarks, copyrights, and trade secrets; as well as establishing clear rules to protect the rights of investors. ${ }^{51}$ Eric Farnsworth points out that

$45 \quad I d$.

46 U.S. Department of State, supra note 2.

47 Id.

48 M. Angeles Villarreal, Cong. Research Serv., RL32934, U.S.-Mexico Economic

Relations: Trends, Issues, and Implications summary (Aug. 9, 2012).

49 Ribando, Cong. Research Serv., supra note 15, at 9.

$50 \quad$ Id.

51 Carla A. Hill, Co-Chair of the Inter-American Dialogue's Board of Directors and Chief Executive Officer of Hills and Company, statement before the House Committee on Foreign Affairs, Subcommittee on the Western Hemisphere: NAFTA at Twenty: Accomplishments, Challenges, and the Way Forward (Jan. 15, 2014). 
"a joint production platform" has been developed among the three North American nations. ${ }^{52}$

In 2012, Mexico joined the negotiations of the Trans-Pacific Partnership (TPP), which will establish "new and higher standards for global trade." This multilateral free trade agreement would likely enhance the economic links that Mexico has already developed with the U.S. and Canada under the NAFTA, for example additional reduction of barriers to trade and negotiation of key issues in various areas (such as agriculture, intellectual property rights, government procurement, regulatory cohesion, among others) ${ }^{54}$

The former Mexican Ambassador to the U.S. Arturo Sarukhan notes that the presence of the three North American countries in the TPP is crucial because it will enable them to discuss measures that face the challenges of "twenty-first-century free and fair trade, such as compatibility of regulatory systems, new environmental provisions, strong protection for intellectual property rights, and emerging areas such as digital technologies and e-commerce."55

Experts have called presidents Obama and Peña Nieto and their administrations to deepen their economic partnership, increase their productivity and competitiveness, and open opportunities for long-term growth and job creation. ${ }^{56}$ In this regard, Luis Rubio suggests that "many of the opportunities for a truly competitive North America lie in combining American technological might and the progressively more productive and competitive Mexican manufacturing base." 57

As part of their High-Level Economic Dialogue, on September 20, 2013, President Peña Nieto and Vice President Biden announced plans to heighten cooperation in border trade and security, so that the transit of people and trade will become faster, safer, and more efficient. ${ }^{58}$

\section{Mexican Government's Perspective}

Over the past three decades, Mexico has had a low economic growth record, with an average growth rate of $2.6 \%{ }^{59}$ Economic volatility and events

52 Americas Society/Council of the Americas, Viewpoints: What Should the Top Priority be FOR U.S.-MEXican Relations? (Apr. 27, 2014)http://www.as-coa.org/articles/ viewpoints-what-should-top-priority-be-us-mexican-relations.

53 U.S. Department of State, supra note 2.

54 Villarreal, Cong. Research Serv., supra note 48, at summary.

55 Americas Society/Council of the Americas, supra note 52, Arturo Sarukhan contribution.

56 Inter-American Dialogue, supra note 1 , at iii.

57 Rubio, supra note 3 , at $5,7$.

58 Maja Wallengren, “Biden, Mexico's Peña Nieto Inaugurate New Initiative to Enhance Trade, Cooperation," International Trade Reporter (Sept. 24, 2013), cited in Ribando, Cong. RESEARCH SERV., supra note 15, at 17.

59 M. Angeles Villarreal, Cong. Research Serv., RL32934, U.S.-Mexico Economic Relations: Trends, Issues, and Implications 11 (Apr. 20, 2015). 
such as the recession of 2001 or the global downturn of 2009 may have affected Mexico's ability to expand at a faster rate. Additionally, violence and security risks may hinder economic growth. ${ }^{60}$ On the other hand, there are factors that may help Mexican economy to grow at a faster rate over the next decades, such as abundant natural resources, a young labor force, and proximity to the United States. ${ }^{61}$

Additionally, the impact of NAFTA - and other reforms to promote open markets and competition- in the Mexican economy is mixed. On the one side, large and medium companies have adopted new and more efficient methods of production by adapting their processes to international standards, situation that allows them to participate successfully in the global market and particularly in the American market. On the other side, there are micro and small businesses that are not integrated with foreign trade; in fact they normally exhibit low productivity and under-professionalization. As a consequence, the Mexican economy still has significant challenges in order to achieve a longterm sustainable economic growth. As McKinsey Global Institute points out:

Special tax breaks for small enterprises, intended to protect traditional businesses, encourage companies to stay small, informal, and unproductive. Mexico can [...] streamline regulatory processes to make compliance easier and examine the remaining labor-law inflexibilities that discourage full-time hiring. Most important of all, to discourage informality the country can redouble its efforts to enforce tax laws and other rules; today, informal businesses employ more than half of nonfarm workers. Mexico needs to become a place where formal, compliant companies grow and prosper -and inspire others to emulate their success- and where companies that do not play by the rules suffer the consequences. ${ }^{62}$

In this sense, President Peña Nieto has presented proposals for improving productivity in different levels of the Mexican economy. For example, through the establishment of the North American infrastructure fund, it is intended to increase the efficiency at the U.S.-Mexican border and deep North American integration. ${ }^{63}$

Similarly, on May 27, 2013 the federal government created a National Productivity Committee in an effort to "democratize productivity" that is defined as to "achieve a more efficient use of the resources used in an economic activity." ${ }^{\text {"Th }}$ The democratization of productivity is attained when tools that

61 Id.

62 Eduardo Bolio et al., A tale of two Mexicos: Growth and Prosperity in a Two-Speed Economy, McKinsey \& Company (Mar. 2014), (Apr. 27, 2014), http://www.mckinsey.com/insights/ americas/a_tale_of_two_mexicos

63 Ribando, Cong. Research Serv., supra note 15, at 16-17.

64 “Democratizar la Productividad para lograr un México Próspero,” (Apr. 27, 2014)http:/ /www.presidencia.gob.mx/democratizar-la-productividad-para-lograr-unmexico-prospero/. 
facilitate work and new technologies of information and communication are incorporated; when the organization of a company and its production processes are modernized; when there is greater access to credit; and when well trained and educated workers are abundant in the labor force. ${ }^{65}$

Although this set of objectives is very ambitious, the first steps could be given through the reforms promoted by President Peña Nieto's government. Their success certainly depends on their implementation (especially in the subnational level), the political equilibrium of the country, and the external shocks of the global economy.

\section{Issues in the U.S. Congress}

The bilateral trade relationship is of key interest to the U.S. Congress because of the circumstances previously described, such as Mexico's proximity, the strong cultural ties between the two countries, and the high volume of trade with Mexico. ${ }^{6}$ According to Ribando, potential questions for congressional consideration include "how U.S.-Mexican trade and economic ties can be deepened, how efficiency on the border can be improved without compromising security, and how weaknesses in NAFTA can be addressed. ${ }^{967}$

The Congress faces numerous issues that could affect the economic relationship with Mexico. ${ }^{68}$ For instance, the U.S. government has sought to go beyond current U.S. free trade agreements (FTAs) in its proposed rules for the TPP, which may have implications for NAFTA in numerous areas. If agreement is reached, for example, the three NAFTA countries would need to adhere to stronger labor and environmental provisions and more stringent rules regarding intellectual property rights. ${ }^{69}$

On the other hand, the Congress will probably continue monitoring NAFTA's institutions: the Border Environment Cooperation Commission and the North American Development Bank. ${ }^{70}$ Congress has also been observing the implementation of NAFTA, the effects of NAFTA on the economies of both nations, and the resolution of NAFTA-related trade disputes. ${ }^{71}$

With regard to the structural reforms that have been passed in Mexico with the purpose of helping reverse years of slow economic growth, as it was previously stated, the administration of President Peña Nieto will need to focus on the implementation of these reforms, in conjunction with appropriate

\footnotetext{
65 Id.

66 Ribando, Cong. Research Serv., supra note 15, at 16.

67 Id. at 18.

68 Id. at 17.

69 Id

70 Id.

71 Id. at 16.
} 
measures to boost economic growth, create more jobs, and fight informality in the labor markets, among other challenges.

In this sense, a crucial interest for the 114th Congress is to monitor the implementation policies for the economic reforms in Mexico by addressing some relevant issues, such as the extent to which the energy reforms will provide opportunities for U.S. oil companies, the improvement that the reforms will cause in the Mexican economic performance, and the complementary measures that Mexican government should take to stimulate economic growth. ${ }^{72}$

\section{MigRATION}

\section{General Overview of U.S.-Mexico Relations}

Immigration is a fundamental aspect of the U.S.-Mexico relationship. History and geography have made the U.S.-Mexico migration flow the largest in the globe. ${ }^{73}$ Mexicans are by far the largest group of immigrants in the U.S., accounting for about 12 million people in 2012 (30\% of all U.S. immigrants). ${ }^{74}$

Undoubtedly, Mexicans are uniquely affected by U.S. immigration policies: they are "the largest group of aliens subject to U.S. immigration control and border security policies, the largest group of lawful immigrants within permanent and temporary visa categories, and the majority of unauthorized migrants within the United States." 75 Taking these facts into consideration, both governments have acknowledged the significance of appropriately regulated immigration. ${ }^{76}$

According to an analysis of government data from both countries by the Pew Hispanic Center, a project of the Pew Research Center (2012), after four decades that brought about 12 million immigrants, the net migration flow from Mexico to the U.S. has stopped and may even have reversed. ${ }^{77}$ The numbers of Mexican people entering the U.S. are now about the same as those leaving. ${ }^{78}$ The standstill of Mexican migration appears to be the result of many factors, such as the weakened U.S. job and housing construction markets, the heightened border enforcement, the increased dangers associa-

72 Villarreal, Cong. Research Serv., supra note 59, at 31-32.

73 Marc R. Rosenblum et al., Cong. Research Serv., R42560, Mexican Migration to the United States: Policy and Trends summary (Jun. 7, 2012).

74 Ribando, Cong. Research Serv., supra note 15, at footnote 40.

75 Rosenblum, Cong. Research Serv., supra note 73, at summary.

76 Inter-American Dialogue, supra note 1 , at 2.

77 Jeffrey S. Passel et al., Net Migration from Mexico Falls to Zero- and Perhaps Less, Pew Research Center, (Apr. 27, 2014) http://www.pewhispanic.org/2012/04/23/net-migrationfrom-mexico-falls-to-zero-and-perhaps-less/

78 Inter-American Dialogue, supra note 1, at 7-8. 
ted with illegal border crossings, a rise in deportations, and the decline in Mexico's birth rates. ${ }^{79}$

At the same time, the number of Mexican-Americans in the U.S. (both immigrants and U.S.-born residents of Mexican ancestry) is continuing to rise. In fact, between 2000 and 2010 births surpassed immigration as the main reason for growth of the Mexican-American population. In 2010, this population numbered 33 million. $^{80}$

Mexicans are currently dispersed throughout all U.S. states. Compared to other migrants, the Mexican born in the U.S. are more likely to be younger, have lower education levels, and work in lower-skilled occupations. ${ }^{81}$ Additionally, in 2012 just over half $(51 \%)$ of all Mexican immigrants in the U.S. were unauthorized..$^{82}$ Regarding this last characteristic, the sharp downward trend in net migration from Mexico previously described has led to the first significant decrease in at least two decades in the unauthorized Mexican population..$^{83}$

What is the best approach to manage the complex issues related to immigration? The Inter-American Dialogue suggests that U.S. and Mexican policies should be directed toward increasing the role of immigration in economic expansion and job growth in both countries, ensuring the respect for the individual rights of immigrants, and curtailing violations of immigration law. ${ }^{84}$ In a similar way, the former U.S. Ambassador to Mexico James Jones suggests that the U.S. must pass comprehensive immigration reform that recognizes the reality regarding labor needs and legal protections for immigrants. ${ }^{85}$

\section{Mexican Government's Perspective}

Mexican government has worked with U.S. law enforcement to combat alien smuggling and human trafficking, and has pledged to enforce legal emigration, increase security in both its northern and southern borders, and create more working opportunities so that fewer individuals emigrate. ${ }^{86} \mathrm{Ne}$ vertheless, corruption remains endemic within the National Migration Institute (office within the Interior Ministry in charge of enforcing immigration

\footnotetext{
79 Passel, supra note 77.

80 Id.

81 Rosenblum, Cong. Research Serv., supra note 73, at summary.

82 Passel, supra note 77.

83 Id.

84 Inter-American Dialogue, supra note 1 , at 2.

85 Americas Society/Council of the Americas, supra note 52, James Jones contribution.

86 Ribando, Cong. Research Serv., supra note 15, at 13.
} 
Esta revista forma parte del acervo de la Biblioteca Jurídica Virtual del Instituto de Investigaciones Jurídicas de la UNAM

laws), Mexico's southern border continues to be insecure, and a lack of employment opportunities persists. ${ }^{87}$

On the other hand, Mexican government has protested that the use of force by U.S. agents on the border is excessive, has defended the rights of Mexican migrants in the U.S., and has challenged state laws against illegal immigration. ${ }^{88}$ Accordingly, the Mexican government has filed amicus curiae briefs in lawsuits seeking to block the immigration laws in Arizona, Alabama, Georgia, South Carolina, and Utah. ${ }^{89}$

Both governments are concerned about the recent increases in Mexicans seeking asylum in the U.S. due to threats of violence in their communities, as well as the rise in Central American migrants in transit through Mexico. ${ }^{90}$ Besides, migrants from Mexico and Central America have become victims of abuses by organized crime, sometimes in collusion with corrupt Mexican officials. $^{91}$

Additionally, Mexican government has been criticized for failing to grant asylum to Central Americans, especially unaccompanied minors. This crisis was particularly serious during 2014. Between January and August of that year, Mexican authorities reportedly apprehended more than 15,795 minors. ${ }^{92}$ This situation implies a double challenge for the country because while it demands better treatment for Mexican immigrants going to the U.S., its authorities are not giving adequate treatment to Central American migrants crossing the country.

President Peña Nieto has pledged his support for efforts to enact a comprehensive immigration reform and is likely to continue efforts to improve border security, enforce its migration policy in a humane way, and create jobs. ${ }^{93}$ Therefore, it seems that the official focus towards migration has to do with improving economic conditions in Mexico and increasing awareness about human rights.

\section{Issues in the U.S. Congress}

Despite the fact that President Obama has put immigration reform at the top of his second-term legislative agenda, ${ }^{94}$ it has been difficult to discuss and 
pass a comprehensive reform due to the weak political equilibrium in the Congress. Specifically, the executive actions that President Obama announced in November 2014 haven't been enacted because they were challenged in the courts of several states. In February 2015, a federal judge in Texas blocked those actions. In January 2016, the U.S. Supreme Court agreed to take the case through which the federal government is fighting the injunction. ${ }^{95}$

The executive actions of President Obama were targeted to improve the immigration system through the expansion of the eligible population for the Deferred Action for Childhood Arrivals (DACA) program and the launch of a new one: Deferred Action for Parental Accountability (DAPA). This program would have allowed parents of U.S. citizens and lawful permanent residents to request also a deferred action against removal and would have allowed them to apply for work authorization, continue studying, among other rights.

Even if these executive actions were implemented to their full extent, they only constitute a partial solution in an immigration system that needs profound changes simply because today there is a different reality and the legal framework has not been adapted to it.

In this regard, The Inter-American Dialogue proposes that a general reform of U.S. immigration legislation "could multiply the benefits of immigration" and that a new policy in this field would open opportunities for millions of individuals and would benefit both economies. ${ }^{96}$ It also observes that the decisive impact of the "Latino vote" on the U.S. presidential election has significantly increased the possibility for a "comprehensive reshaping of immigration policy." 97 Both Republicans and Democrats, it explains, have strong incentives to tackle immigration because they are aware of "the unprecedented turnout of Latino voters and the fact that their numbers will be substantially larger in subsequent elections." 98

In this sense, the Development, Relief, and Education for Alien Minors Act (DREAM Act) is a proposed federal law that authorizes the Secretary of Homeland Security to cancel the removal of certain undocumented youth by giving them the possibility to obtain permanent legal status and even citizenship.

Several versions of the DREAM Act have been introduced in the U.S. Congress during the last 14 years. The earliest versions were not brought to a vote. In 2006, the DREAM Act was included in a bipartisan comprehensive immigration reform act that also failed to win congressional support. The bill had its best chance of passing during 2010 but it suffered a setback in the Senate. ${ }^{99}$

More recently, during the last legislative period (113 $3^{\text {th }}$ Congress), a new version of the DREAM Act was included in the Senate's immigration reform

95 Citizen Path, DAPA and Expanded DACA Status (2016), available at https://citizenpath. com/dapa-expanded-daca-status/

96 Inter-American Dialogue, supra note 1 , at 7.

97 Id. at 8 .

98 Id.

99 See Schmid, Carol L., Undocumented childhood immigrants, the Dream Act and Deferred Action for Childhood Arrivals in the USA, 693 InT'L J. Soc. \& Soc. POL'Y (2013). 
bill: Border Security, Economic Opportunity, and Immigration Modernization Act (S. 744), approved in June 2013. If the House of Representatives approves it, this bill would -among other things- approximately double recent investments in border security; establish three programs designed to potentially offer lawful residency to most existing unauthorized immigrants; and revise rules for permanent and temporary immigration to the U.S. ${ }^{100}$

In the House, five different immigration bills received committee attention in 2013. ${ }^{101}$ In May, the House Homeland Security Committee reported favorably on the Border Security Results Act of 2013 (H.R. 1417), which would require the Department of Homeland Security to develop a strategy to secure the southern border, along with new border security metrics. In June, the House Judiciary Committee marked up four bills. ${ }^{102}$ First, the Strengthen and Fortify Enforcement Act (SAFE Act, H.R. 2278) would encourage states and localities to play a larger role in immigration enforcement and heighten penalties for violations of federal immigration law. Second, the Agricultural Guest Worker Act (H.R. 1773) would create a new temporary agricultural worker visa designed to be more flexible than the existing one. Third, the Supplying Knowledge-based Immigrants and Lifting Levels of STEM Visas Act (SKILLS Visa Act, H.R. 2131) would expand permanent and temporary visa programs for high-skilled workers. Finally, the Legal Workforce Act (H.R. 1772) would require employers to use the E-Verify electronic employment eligibility verification system and would create a larger role for states in the enforcement of employment-related immigration law. ${ }^{103}$

With the purpose of modernizing the U.S.-Mexico border, during the last years, the U.S. Congress has authorized pilot programs to enter into publicprivate partnerships with certain localities, permitted the private sector to fund improvements in border facilities and port services, and provided funding for additional customs inspectors and infrastructure. ${ }^{104}$

As part of the debate about immigration policy and border issues, Ribando notes that one question that may arise is if Mexico should be treated as a "special case" on the immigration field given Mexico's status as the U.S. neighbor. ${ }^{105}$ In this regard, the Latin-American Dialogue suggests that a special bilateral arrangement governing the cross-border migration flow merits consideration by both countries because the two of them "have important stakes, both political and economic, in a predictable, regulated migration stream." $" 106$

\footnotetext{
100 Ribando, Cong. Research Serv., supra note 15, at 14.

101 Id.

102 The four Judiciary Committee bills were referred to other committees with jurisdiction over them. However, House Members appear to be divided regarding which of these bills should be brought to the House floor (Id. at 15).

103 Id. at 14-15.

104 Ribando, Cong. Research Serv., supra note 43, at 22-25.

$105 I d$. at 25.

106 Inter-American Dialogue, supra note 1 , at 9.
} 
Esta revista forma parte del acervo de la Biblioteca Jurídica Virtual del Instituto de Investigaciones Jurídicas de la UNAM

\section{ENERGY}

\section{General Overview of U.S.-Mexico Relations}

Although Mexico has been a consistent and top crude oil supplier to the U.S., Mexico's oil production has declined significantly in recent years. ${ }^{107}$ As it will be analyzed in the next section of this work, in December 2013 President Peña Nieto signed into law a constitutional reform related to the energy sector with the purpose of reversing those declines. This historic reform permits Mexico's state oil company, Petróleos Mexicanos (Pemex), to partner with international companies to propel production. ${ }^{108}$ Depending upon the provisions and implementation of the secondary legislation, significant investment opportunities for U.S. companies could be created, the U.S.-Mexican energy trade could be increased, and North American competitiveness could be bolstered. ${ }^{109}$

The future of oil and natural gas production in Mexico is crucial for both Mexico's economic growth and U.S. energy security, which is a "a key congressional interest." 110 As a result, the U.S. has a national interest in ensuring that Mexico "is economically vibrant and politically stable" and U.S. policy makers are likely to closely monitor the implementation of the Mexican reforms on the energy sector. ${ }^{11}$

Energy sufficiency has been one of the key long-term issues of interest for the U.S. Therefore, a change in its neighbor regulation towards oil, gas, and other fuels not only represents an opportunity for American companies to sell technology and infrastructure or invest in productive partnerships, but also means securing new fuel sources for the whole continent. This will strengthen both the Mexican and American energy security by lowering their dependence from other markets.

\section{Mexican Government's Perspective}

The Mexican energy reform bill took effect on January 1, 2014 and "formalizes the most liberal energy regime in the country's history." 112 The

107 Clare Ribando Seelke et al., Cong. Research Serv., R43313, Mexico’s Oil and Gas Sector: Background, Reform Efforts, and Implications for the United States summary (JAN. 6, 2014).

108 Id. at 1.

109 Id. at summary.

110 Id.

111 Id. at 1.

112 David Enríquez, Mexico's Energy Reform: A Game Changer in the Nation's History (An Upstream Perspective), Mexico Institute of the Woodrow Wilson International Center for Scholars, at 1 (2014), available at http://www.wilsoncenter.org/publication/mexico $\% \mathrm{E} 2 \% 80 \% 99 \mathrm{~s}-$ energy-reform-game-changer-the-nation $\% \mathrm{E} 2 \% 80 \% 99 \mathrm{~s}$-history-upstream-perspective-0. 
reform addresses three key aspects: authorizing private investment for exploration and extraction of hydrocarbons under contracts with the federal government; allowing private investment for electricity generation, commercialization, transmission and distribution under contracts with the Electricity Federal Commission; and permitting oil processing and refining by private companies as well as gas processing, oil and oil derivatives transportation, storage and distribution. ${ }^{113}$

Although the constitutional provision that establishes the hydrocarbons' ownership by the country (and thus prohibits concessions) remained intact, the reform unfolded a new oil and gas strategic area and offered new business opportunities. $^{114}$

According to the bill's transitional clauses, Pemex and the Electricity Federal Commission will progressively become "productive state companies" that will be able to compete with other enterprises. For this reason, their workforce and investment priorities must be restructured. Both companies will be provided with greater managerial and technical autonomy and will be subject to financial balance and income taxes as any other private company. ${ }^{115}$

As a consequence of this change, Pemex will pass its oil and gas traditional power to the National Hydrocarbons Commission as the new manager of the resource, and to the Energy Ministry as the policy maker. ${ }^{116}$ Similarly, the Electricity Federal Commission will pass its energy generation dispatch function to Center for Energy Control, which is the new autonomous agency that will be the technical operator of the electricity in the country. These situations exemplify the key challenge that Mexico has in strengthening the role that regulators have in the new energy market.

The bill introduces four different types of contracts for exploration and production: service contracts under which companies are paid for activities done on behalf of the state; profit-sharing contracts, with a compensation based on a percentage of profit; production sharing contracts, with a compensation based on a percentage of production; and license contracts that enable a company to obtain ownership of the oil or gas at the wellhead after it has paid taxes. ${ }^{117}$ The bill also allows as a fifth alternative any combination of the above-mentioned contracts. Although this provision may allow a great similarity with the concession model, such flexibility depends on the secondary legislation to implement the reform. ${ }^{118}$

As this provision, many important details left for the secondary laws are crucial for attracting oil companies to Mexico. For instance, this legislation

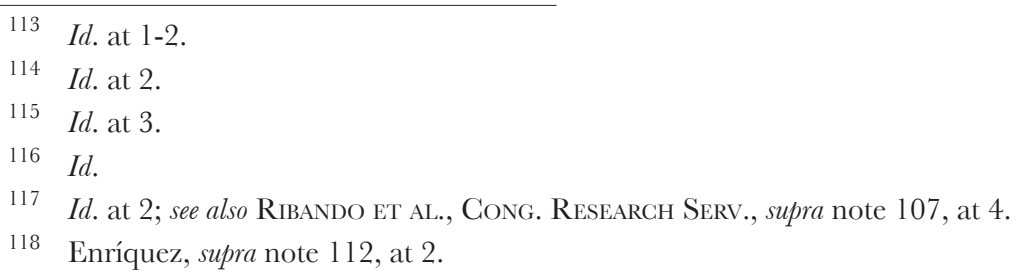


needs to define the terms under which private firms may be involved in upstream operations, establish transparency and anti-corruption measures, and determine the duties of the regulatory entities. ${ }^{19}$

In conclusion, the major challenge in the energy sector is to achieve an effective regulation that provides clear rules to all national and international actors and incentivizes investment, while Mexico continues to strengthen internal economic and security conditions to ensure the operability of the legal changes.

\section{Issues in the U.S. Congress}

According to the CRS, the opening of the Mexican oil and natural gas sector to foreign investors poses substantial changes in the U.S.-Mexico relationship that may have advantages and disadvantages for both nations. ${ }^{120}$ Reversing Mexico's production decline would add more oil to the global market, heighten U.S. energy security, and contribute to North American energy independence. Besides, depending upon the terms and implementation of the secondary legislation, U.S. companies could be benefited from the opening of Mexican resources to foreign investment. While this could be true for some sectors, U.S. natural gas producers who export natural gas to Mexico might lose their market. ${ }^{121}$ For these reasons, the U.S. Congress has "legislative and oversight interests in examining the potential implications" of the Mexican energy reform. ${ }^{122}$

Another crucial congressional interest has been the management of energy resources in the deep-water areas of the Gulf of Mexico. ${ }^{123}$ In 2012, the U.S.-Mexico Transboundary Hydrocarbons Agreement ${ }^{124}$ was signed to start an energy partnership and facilitate joint development of oil and natural gas in part of the Gulf of Mexico. ${ }^{125}$ Under the agreement, the two countries establish a framework for jointly developing 1.5 million acres along a 550-mi-

119 David L. Goldwyn, Mexico Rising: Comprehensive Energy Reform at Last? A AtLantic CounciL (Dec. 2013), http://wrwreatlanticcouncil.org/images/publications/Mexico_Rising.pdf, cited in RIBANDO et al., Cong. Research Serv., supra note 107, at 5.

120 Ribando et al., Cong. Research Serv., supra note 107, at 15.

121 Id.

122 Id. at summary.

123 Gurry L. Hagerty \& James C. Uzel, Cong. Research Serv., R43204, Legislation Proposed to Implement the U.S.-Mexico Transboundary Hydrocarbons Agreement summary (2013).

124 Officially titled as "Agreement between the United States and Mexico Concerning Transboundary Hydrocarbon Reservoirs in the Gulf of Mexico."

125 It is estimated that this area of international waters contains about 172 million barrels of oil and 304 billion cubic feet of natural gas. 
le border and agree to dismantle a treaty-based moratorium on oil and gas development agreed to in $2000 .^{126}$

U.S. legislation to approve and implement the agreement includes H.R. 1613 (passed by the House on June 27, 2013) and S. 812 (passed by the Senate on October 14, 2013). ${ }^{127}$ Committee chairs and ranking members in both chambers have pledged expeditious approval of the proposed implementing legislation. ${ }^{128}$ Opponents have expressed objections to certain provisions of H.R. 1613 alleging that they involve issues beyond implementing the agreement. ${ }^{129}$

In addition, legislation dealing with U.S. approval processes for North American energy infrastructure has been introduced (H.R. 3301). ${ }^{130}$ This is particularly relevant given that the opening of Mexico's oil and natural gas sector could "provide opportunities for U.S. companies and investors involved in the hydrocarbons sector, as well as infrastructure and other oil field services." 131

Accordingly, Congress oversight may focus on the implementation of the Transboundary Hydrocarbons Agreement; the extent to which Mexico is developing independent and capable regulators for the energy sector; and the fairness of the terms Mexico offers to private companies interested in investing. ${ }^{132}$

\section{OTHER RELEVANT IsSUES}

\section{Human Rights}

While some bilateral issues require immediate congressional attention in order to advance, others "may lend themselves more to long-term oversight." Ribando suggests that congressional concerns about improving human rights conditions and strengthening democracy in Mexico fall into the second category. ${ }^{134}$

Concerns about human rights conditions in Mexico have intensified as U.S. security assistance to Mexico has increased under the Mérida Initiative. ${ }^{135}$ With the purpose of ensuring that U.S.-funded anticrime efforts are

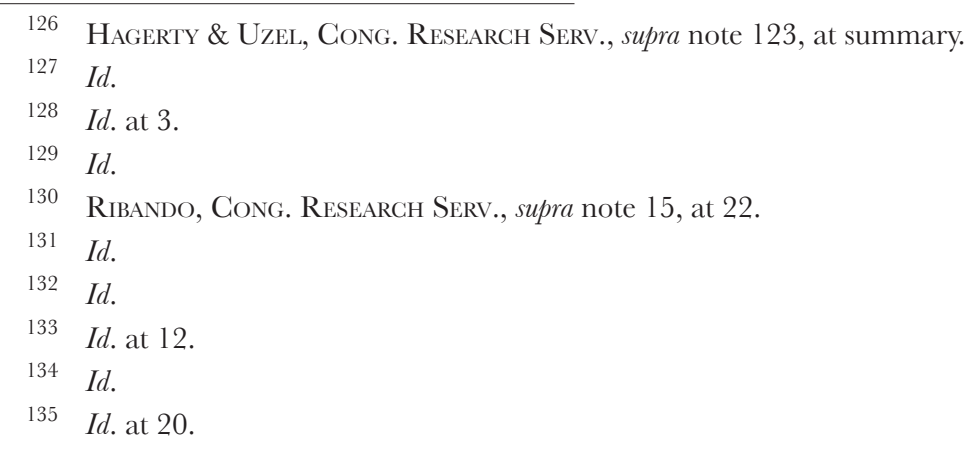


carried out in a way that respects human rights, Congress has conditioned U.S. assistance to the Mexican military and police on compliance with certain human rights standards and has provided funding to protect vulnerable groups (such as the press and human rights defenders) and to support human rights training for security forces. ${ }^{136}$

As it was previously noted, U.S. assistance to Mexico has increasingly focused on supporting Mexican government's efforts to reform its justice system. Particularly, Congress has targeted money to support the transition from an inquisitorial justice system to an oral, adversarial, and accusatory one. Moreover, the U.S. Agency for International Development (USAID) expanded its program to support judicial reform from seven to twenty states. ${ }^{137}$

In this sense, human rights conditions in Mexico are likely to constitute an important oversight issue in the U.S. Congress. For instance, Congress may choose to increase Mérida Initiative funding for ongoing human rights programs (such as the above-mentioned training programs) or for newer efforts (such as support for human rights organizations). ${ }^{138}$

\section{Border Issues}

The U.S. Congress must consider the U.S.-Mexico border situation in both policy- and law-making processes. As it has been studied here, interdependence is an essential feature of the U.S.-Mexico relationship. This interdependence is particularly pronounced along the border. ${ }^{139}$ In fact, the complex mix of local, state, national, and international policy issues of the border has been described as the best counterexample to the traditional notion that domestic politics are distinct from foreign policy. ${ }^{140}$

At the border, the U.S. and Mexico must manage complex problems and shared opportunities regarding a wide variety of issues, such as natural resources, transnational criminal groups, and trade. Therefore, border management has implications that go "far beyond the border region itself." ${ }^{141}$ Given the immense trade flows, misguided policies can impose tens of billions of dollars of costs on consumers each year. Poor security coordination along the frontier could prove deadly and, in some cases, disastrous. Mismanagement

\footnotetext{
136 Id.

137 Ribando, Cong. Research Serv., supra note 43, at 17-18.

138 Id.

139 Pacific Council on International Policy \& Comexi (Consejo mexicano de Asuntos Internacionales), Managing the United States-Mexico Border: Cooperative Solutions to Common Challenges 8 (2009).

140 Woodrow Wilson International Genter for Scholars et al., The State of the Border Report: A Comprehensive Analysis of the U.S.-Mexico Border 4(Woodrow Wilson International Center 2013) (2013).

141 Id. at 5.
} 
Esta revista forma parte del acervo de la Biblioteca Jurídica Virtual del Instituto de Investigaciones Jurídicas de la UNAM

of shared resources can lead to scarcity and environmental degradation. ${ }^{142}$ Consequently, the public-policy design for this area needs a comprehensive and careful analysis. ${ }^{143}$

Given these circumstances, "cooperative binational solutions are often the only solutions." "144 While the U.S. State Department and Mexico's Foreign Ministry formally manage federal government-to-government interaction, a number of federal and state agencies are also involved in the border management. Interagency coordination is crucial and can be difficult because local governments must conduct international work with their counterparts in the U.S. or Mexico. ${ }^{145}$

The ten U.S. and Mexican border states actively participate in the border liaison mechanisms, which operate in "sister city" pairs and have proven effectiveness while dealing with a variety of problems. ${ }^{146}$ Binational collaboration in this regard not only benefits localities but also makes "vital contributions to international stability and prosperity." 147 This shows that the most important public policy or common problems along the border usually have their solution in regional agreements and not in policies dictated from the center of the federal system.

\section{Water Sharing}

Pursuant to binational agreements, the U.S. and Mexico share the Colorado River and Rio Grande. ${ }^{148}$ Compliance with these agreements has become more complicated as water demands nears or exceeds available supplies. ${ }^{149}$

The Colorado River flows through seven U.S. states before reaching Mexico and $97 \%$ of the basin is in the U.S. A 1944 Water Treaty requires the U.S. to annually provide Mexico with 1.5 million acre-feet of Colorado River water (about $10 \%$ of the river's average flow). Under the treaty, disputes can be resolved through amendments called "minutes." Minute 319 (agreed to in 2012) "provides for a bilateral basin water management, storage, and environmental enhancement effort." ${ }^{150}$ On the other hand, Rio Grande is go-

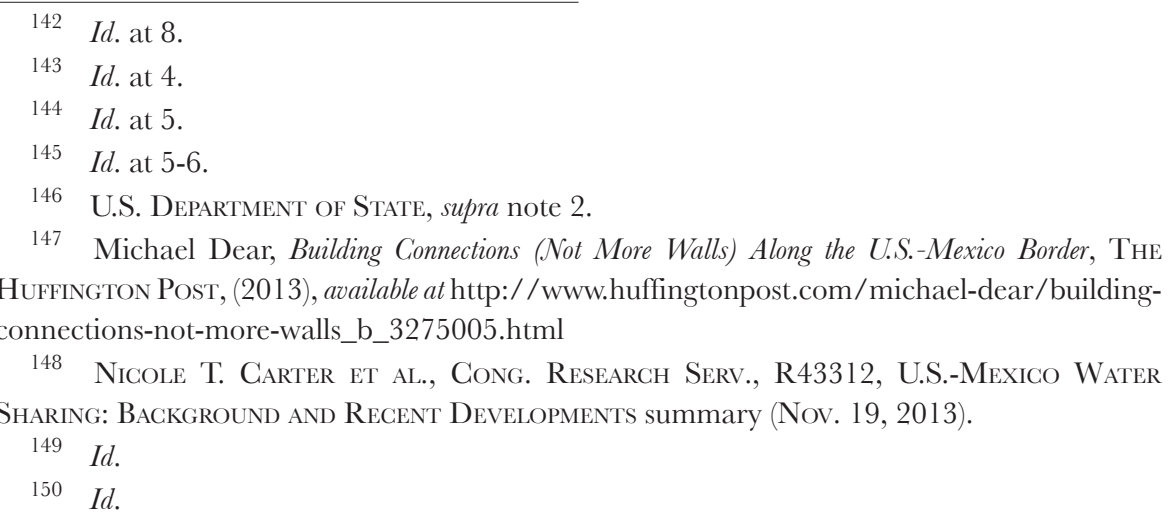


verned by two different agreements. Deliveries to Mexico in the northwestern portion of the basin are laid out in the 1906 Convention, while deliveries for the southeastern portion occur under the 1944 Water Treaty. ${ }^{151}$

Some Members of Congress are concerned about Mexico's 1944 Water Treaty compliance, the resulting economic impacts, and the adequacy of U.S. government efforts to press Mexico to comply with its treaty obligations. ${ }^{152}$ Moreover, various bills ${ }^{153}$ include provisions to require further reporting on Mexico's efforts to meet its Rio Grande water deliveries and on the implementation of Minute 319 regarding the Colorado River. ${ }^{154}$

\section{Regional and Global Issues}

U.S.-Mexico cooperation is increasing on regional and global issues. Diverse matters in the international arena deeply concern both countries, such as security threats in Central America, reforming multilateral organizations, building new trade partnerships worldwide, and problems of nuclear nonproliferation and climate change. ${ }^{155}$ As the Inter-American Dialogue notes, even if the two nations disagree on some of these issues, "they remain natural partners" and the U.S. and Mexico "can best meet the current challenges of global instability and uncertainty by stepping up efforts toward economic integration." 156

\section{Goncluding Remarks}

- The relations between the U.S. and Mexico are complex because they involve far-reaching commercial and cultural bonds. This bilateral relationship has a direct impact on the lives of millions of persons. Given the interdependence between the two countries, the success of Mexico in resolving its difficulties has a major impact upon the U.S. For these reasons, U.S.-Mexico relations are a key interest for the U.S. Congress.

- U.S.-Mexico relations have been evolving and issues in the bilateral agenda have been steadily expanded. From an emphasis on immigration issues, economy or security (more recently), now other critical is- 
sues appear, such as natural resources or energy, which will probably dominate the dialogue between the two nations during the next years.

- Under the administration of President Peña Nieto, a variety of significant structural reforms have been enacted. Since these reforms were made on the constitutional level, they must be translated into specific laws and regulations. As Mexico is experiencing this major transformation, its relations with the U.S. are also evolving. This transition will probably imply new challenges with regard to different aspects of the bilateral relationship.

- In the security field, President Peña Nieto's new strategy is focused on reducing violent crime and the process and priorities of U.S.-Mexican efforts had been adjusted in that sense. President Obama has supported these adjustments. If the Congress finds that the Mexican security strategy has no longer the same priorities as the U.S., Congress may consider reevaluating certain types of Mérida Initiative funding.

- Mexican economic prosperity is relevant for the U.S. national interests and, on the other hand, Mexican economy is heavily dependent on the U.S. The Congress faces numerous issues that could affect the economic relationship with Mexico, such as the U.S. government proposal of going beyond current U.S. free trade agreements in its proposed rules for the TPP; the monitoring of NAFTA's institutions and its effects on the economies of both nations; and the resolution of NAFTA-related trade disputes.

- Mexico's role in the U.S. immigration system creates a number of both opportunities and challenges. Mexicans are uniquely affected by U.S. immigration policies. It has been suggested that a comprehensive immigration reform that recognizes labor and legal protection needs of the immigrants must be passed. Nonetheless, if an integral reform is not attainable in the short term, immigration will still be receiving substantial attention in both chambers of the Congress.

- With regard to the energy sector, the future of oil and natural gas production in Mexico is crucial for U.S. energy security and for this reason is a relevant congressional interest. Depending on the provisions and implementation of the secondary legislation of Mexico's constitutional reform, significant investment opportunities for U.S. companies could be created, the U.S.-Mexican energy trade could be increased, and North American competitiveness could be bolstered. Congress is likely to study the fairness of the terms Mexico offers to private companies interested in investing. Additionally, congressional oversight may focus on the implementation of the Transboundary Hydrocarbons Agreement.

- Finally, the complexity of the U.S.-Mexico relationship is reflected in the multiplicity of important topics that should be taken into account in the policy- and law-making processes. These topics will definitively 
Esta revista forma parte del acervo de la Biblioteca Jurídica Virtual del Instituto de Investigaciones Jurídicas de la UNAM

have a crucial weight and presence in the bilateral dialogue. Firstly, human rights conditions in Mexico will continue to be an important issue in the U.S. Congress. Secondly, Congress must consider the U.S.-Mexico border situation in order to anticipate and solve problems that could arise from the intense economic and cultural exchanges that happen in the border area. Thirdly, Congress may monitor Mexico's compliance of the binational agreements under which the U.S. and Mexico share the Colorado River and Rio Grande. Lastly, U.S.-Mexico cooperation is also increasing on diverse regional and global matters. 